\title{
JYD
}

http://jyd.pitt.edu/ | Vol. 12 Issue 3 DOI 10.5195/jyd.2017.497 | ISSN 2325-4017 (online)

\section{Urban Youth Perceptions of Agriculture}

\author{
Sharon Jean-Philippe \\ University of Tennessee \\ jeanphil@utk.edu \\ Jennifer Richards \\ University of Tennessee \\ jennifer.richards@utk.edu \\ Kimberly Gwinn \\ University of Tennessee \\ alesgwin@ut.utm.edu \\ Caula Beyl \\ University of Tennessee \\ cbeyl@utk.edu
}

This is a correction to the original article. For information about the changes made, please see the erratum http://dx.doi.org/10.5195/jyd.2017.577.

\begin{abstract}
To change public perceptions, particularly from urban populations, of agriculture and natural resources (ANR) fields, the University of Tennessee developed a model of strategic educational recruitment to extend beyond traditional college fair experiences to educate underrepresented candidates. The High School Agricultural Education Initiative (HSAI) provided $10^{\text {th }}$-grade students with opportunities to: (a) gain knowledge of and appreciation for disciplines in agriculture and natural resources, (b) learn about college admissions standards, (c) network with college students and staff to learn about campus resources, and (d) understand how a college education improves professional opportunities. The HSAI ( $\mathrm{n}=122$ ) was effective at increasing urban high school student knowledge of postsecondary opportunities in agriculture and natural resources, particularly with regards to ANR career paths. Additionally, students placed high value on the importance of scholarships and they believed that their parents would be supportive of majoring in an ANR discipline. The HSAI program targeted $10^{\text {th }}$-grade students for a one-time intervention, however, in further reflection and based on the results of this study, establishing long-term partnerships with Title I urban high schools may be more effective at increasing the number of youth who actually apply and enroll in ANR programs in college.
\end{abstract}

(c) $\mathrm{EY}_{\mathrm{EY}}$ New articles in this journal are licensed under a Creative Commons Attribution 4.0 License. This journal is published by the University Library System, University of Pittsburgh and is cosponsored by the University of Pittsburgh Press. The Journal of Youth Development is the official peer-reviewed publication of the National Association of Extension 4-H Agents and the National AfterSchool Association. 
Urban Youth Perceptions of Agriculture

Key words: agricultural and natural resources education, agricultural careers, college-high school partnerships

\section{Introduction}

Many factors affect the decision-making process of urban students entering post-secondary education. Among these influencers are career self-efficacy, values, financial incentives, exposure to agriculture, and family attitudes about career choice (Boekeloo et al., 2015; Flemming \& Grace, 2015; Martin, Erete, \& Pinkard, 2015; Outley, 2008). Three potential barriers to enrollment of urban minorities in agriculture are the lack of (a) contact with program recruiters, (b) interest in agriculture, and (c) awareness of on-farm opportunities (Drew et al., 2015; Smith \& Baggett, 2012; Dumas, 2014).

Title I schools are defined as those that have high percentages of youth from low-income families (U.S. Department of Education, n.d.). In many of these schools, particularly those located in urban areas, the percentage of underrepresented minorities is abundant (U.S. Department of Education, National Center for Education Statistics, 2007). In addition, these youth typically have little or no experience in the agricultural sciences and tend not to apply to colleges with a focus on agriculture. Data collected by the College of Agricultural Sciences and Natural Resources (CASNR) at the University of Tennessee show only $12.5 \%$ of students enrolled during the Fall 2016 semester were minorities (Office of Institutional Research, 2017).

In order to address this issue and attract students of high academic caliber, CASNR partnered with a local urban Title I school and together developed the High School Agricultural Education Initiative (HSAI). This initiative provided $10^{\text {th }}$-grade students from an urban Title I school with opportunities to (a) gain knowledge of and appreciation for ANR disciplines, (b) learn about college admissions standards, (c) network with college students and staff to learn about campus resources, and (d) understand how a college education improves professional opportunities. The purpose of this study was to determine if student perceptions were impacted by short-term HSAI programming focused on ANR.

\section{Relevant Scholarship}

The theoretical framework for this study was based on the Social Cognitive Career Theory (SCCT) developed by Lent, Brown and Hackett (1994). Embedded in Bandura's (1986) general social cognitive theory, SCCT encompasses several cognitive personal variables (e.g. selfefficacy, outcome expectations, and goals), and the interaction of these variables with other 


\section{Urban Youth Perceptions of Agriculture}

components of a person's life (e.g. gender, ethnicity, social support and barriers) that help shape career development. Swanson (1972) postulated that as a person's knowledge and experience with ANR disciplines increases, his or her positive connotations toward the field will increase as well, potentially leading to desired attitudinal changes such as pursuing ANR majors. Osborne and Dyer (2000) suggested it was theoretically possible to gauge intentions of students' interest in pursuing ANR majors and career paths by determining their existing knowledge and attitudes toward agriculture. Osborne and Dyer recognized the essential role parents and other significant adults play in determining students' perceptions of agriculture and ANR majors (Scofield, 1995; Thompson \& Russell, 1993). They concluded that by engaging both parents and students in educational experiences related to agriculture, positive attitudes toward ANR majors could increase (Osborne \& Dyer, 2000).

Several studies have investigated how students prepare for career choices based on learned norms, values, behaviors and social skills acquired during the academic major selection (Kuijpers, Meijers, \& Gundy, 2011; Toyokawa \& McLoyd, 2011). Notable factors contributing to students' selection of academic majors include educational and income levels of parent(s), early exposure, industry knowledge and substantive exposure at postsecondary and collegiate levels (Anderson \& Kim, 2009; Jones and Bowen, 1998; Mason \& Hansen, 2004). An individual's decision to pursue ANR majors is influenced by ones' socialization within these fields and the perceived benefits of future career opportunities (Henry, Talbert, \& Morris, 2014; Vincent, Henry, \& Anderson, 2012). For example, Faze, Wingenbach, Rutherford, \& Wolfskill (2011) found that students' attitudes shifted from neutral to positive attitudes toward ANR as a college major after summer workshops that emphasized everyday interactions with agriculture (e.g., clothing, food, shelter, water) for urban students.

However, a number of studies have shown that minority youth do not receive the requisite knowledge or experiences necessary to develop positive attitudes toward ANR and that this lack of exposure creates a disconnect that prevents students from considering ANR-related careers (Arrington and Price, 1983; Bowen, 1987; Bowen, 1994; Bowman \& Shepard, 1985; Hunte, 1992; Larke \& Barr, 1987; Lawrence, Rayfield, Moore, \& Outley, 2013; Rawls \& Thomas, 1994; Wiley, Bowen, Bowen, \& Heinsohn, 1997). Many of these studies concluded early exposure to agricultural experiences and career paths during the middle and high school years could be a critical element toward positively influencing the agricultural perceptions and attitudes of youth. 


\section{Program Description}

\section{HSAI Program Development}

The research team was awarded a $\$ 10,000$ seed grant ${ }^{1}$ to develop partnerships and programing to recruit underrepresented students into the STEAM pipeline (note: STEAM = Science, Technology, Engineering, Agriculture and Math) through existing high school programs. From that initial program, the principal at our partner high school solicited CASNR to develop similar programming for their students as part of a $10^{\text {th }}$-grade college pre-recruitment initiative. The HSAI represents a partnership among the University of Tennessee, CASNR, the high school and the City of Knoxville. In 2013, the high school students attended the HSAI program, but no data was collected. The program was repeated in 2014 as part of the study presented here.

\section{HSAI Participants}

The HSAI was conducted in 2014 with a volunteer sample of $10^{\text {th }}$-grade students $(n=122)$ from an urban Title I high school located 4 miles north of the University of Tennessee. The high school's administration set the criteria for participation in the HSAI. These criteria included: (a) completion of the requisite course credits to be considered a sophomore, (b) positive behavior, and (c) persistent attendance. The sample was comprised of 51\% female participants, $49 \%$ male; $53 \%$ of the students were underrepresented (47\% African-American, and $6 \%$ Hispanic). Demographic data for the participants was provided by the high school and was not included in the questionnaire used in this study. Participation was voluntary and dependent upon receipt of parental consent and student assent which were sent home 4 weeks prior to the program. This program was executed under the approval of the University of Tennessee's Institutional Review Board.

\section{HSAI Program Delivery}

In order to support the goals of the HSAI, students participated in a rotation of activities and programs on campus that were aimed at ANR education and college exposure. ANR-educationfocused activities included an academic browse session at which representatives from each department within the college were invited to provide information on programs available in their departments and to speak informally with students regarding various academic disciplines.

${ }^{1}$ College of Agricultural Sciences and Natural Resources Collaborative and Innovative Teaching Grant (Internal Award 2013-2014). 


\section{Urban Youth Perceptions of Agriculture}

Departments sent undergraduate or graduate student representatives (CASNR Ambassadors) to speak with participants in an intentional effort to promote student interaction, connection and engagement. CASNR departments created interactive booths and exhibits for participants in an effort to truly open students' eyes to the world of agricultural sciences (e.g., Animal Science showcased cow stomach cavities; Food Science and Technology conducted a food tasting exhibit with chocolate; and Forestry, Wildlife and Fisheries displayed animal pelts, fishery specimens and arboriculture equipment). These engaging booths provided students with opportunities to see agriculture in action, speak with representatives, and obtain a new and deeper understanding of the agricultural industry. For many of the student participants, this was their first time speaking with representatives regarding areas of study within ANR. Program organizers also invited representatives from other colleges throughout the University of Tennessee including the Colleges of Business; Social Work; Engineering; and Education, Health and Human Sciences. The Graduate School and the Offices of Admissions and Financial Aid also participated to provide students with short- and long-term information about the college application and funding process.

To kick off the college exposure activities, students completed a walking tour of the west campus of the university, where the College of Agriculture facilities are housed; the tour included the botanical gardens, greenhouses, food science laboratories, plant science laboratories, and the College of Veterinary Medicine. In addition, participants completed a bus tour of the remainder of the university campus and were provided with vital information regarding residence halls, student support services and campus recreational activities. Students then completed a private tour of the football stadium by faculty and students whose academic interests included turf management, landscape architecture, and plant sciences. After the tours were completed, participants viewed BRIDGE - Five Issues that the USDA Thinks Must be Tackled, $^{2}$ a 5-minute video developed as part of a USDA HEC project, ${ }^{3}$ outlining USDA Priority Areas, the importance of agricultural research and projected employment opportunities in the ANR sciences.

\footnotetext{
${ }^{2}$ This video can be viewed at http://www.youtube.com/watch?v=Gq-w9TTv4xE.
}

${ }^{3}$ U.S. department of Agriculture Higher Education Challenge (USDA HEC) project TENE-2011-01826. 


\section{Urban Youth Perceptions of Agriculture}

\section{Methods}

\section{HSAI Questionnaire}

For this program we used a questionnaire developed as part the USDA HEC project. The project's research team identified questionnaire items used in previous studies with similar purposes (Cecchettini, Sommer, \& Leising, 1992; Dyer, Breja, \& Andreasen, 1999; Dyer, Lacey, \& Osborne, 1996; Faulkner, Baggett, Bowen, \& Bowen, 2009; Wildman \& Torres, 2001) in their assessments of attitudes about ANR majors and careers. A panel of experts in ANR disciplines, instrument development, and adolescent education reviewed the final questionnaire for item consistency, quality of items, and appropriateness of reading level. The questionnaire contained 20 Likert-type items (with 5 responses ranging from $1=$ strongly agree to $5=$ strongly disagree). Questions focused on (a) changes in perceptions of ANR majors, (b) knowledge of ANR careers, and (c) knowledge of current issues in ANR disciplines (see Appendix for instrument). The questionnaire was field-tested with a similar population of students from a different high school and found to be reliable $(\alpha=.70)$.

In the present study, the questionnaire was administered twice. A pretest was provided with the parental consent and student assent forms, and once parental consent was obtained, the students completed the test and returned to their high school teacher. Students completed the pretest approximately four weeks in advance of the on-campus programming. The posttest, which was identical to the pretest, was administered onsite at the conclusion of the Academic Browse Session.

\section{HSAI Questionnaire Analysis}

Using SPSS (version 19.0), descriptive statistics were examined for the entire data set. A paired samples t-test was used to compare the pre- and post-questionnaires. Likert scores of 3.5 or greater were regarded as positive student perceptions and scores of 2.5 or lower were regarded as negative student perceptions. Scores between 2.5 and 3.5 were regarded as neutral.

\section{Findings}

The urban $10^{\text {th }}$-grade students that participated in the HSAI program had a positive perception of ANR as a science. Statements regarding the technical and scientific aspects of the ANR sciences had positive scores (Table 1). These findings are similar to an earlier study on the perceptions of $10^{\text {th }}$ graders (Newsom-Stewart \& Sutphin, 1997). The HSAI students placed high 


\section{Urban Youth Perceptions of Agriculture}

value on the importance of scholarships (Table 1). The students evaluated their knowledge of current issues in ANR disciplines as high; they believed that their parents would support the decision to major in an ANR field, and that their choice of a career should make a positive impact on society (Table 3). Prior to the HSAI, most students had thought about a college and major to pursue. Participation in the HSAI program resulted in positive changes in students' perception of agriculture and focus on scholarships (Table 1) as well as knowledge of ANR careers (Table 2).

\section{Changes in perceptions of ANR majors}

One of the most important outcomes of the program is that students left with an improved perception of agriculture. After attending the HSAI program, students considered ANR to be a more scientific area of study $(p=0.008)$ and a more highly technical field $(p=0.001)$ than they originally believed (Table 1 ). Mean responses as to whether students had decided on a

Table 1. HSAI Survey Items Focused on Perceptions of Agricultural Science and Natural Resources (ASNR) Majors

\begin{tabular}{|c|c|c|c|c|c|c|c|c|}
\hline & \multicolumn{2}{|c|}{ Pre } & \multicolumn{2}{|c|}{ Post } & \multirow[t]{2}{*}{ Diff. } & \multirow[t]{2}{*}{$\mathbf{t}$} & \multirow[t]{2}{*}{ df } & \multirow{2}{*}{$\begin{array}{l}\text { Effect } \\
\text { size }\end{array}$} \\
\hline & Mean & SD & Mean & SD & & & & \\
\hline $\begin{array}{l}\text { Scholarship offers are the most } \\
\text { important factor for choosing a } \\
\text { college or a major. }\end{array}$ & 3.86 & 1.03 & 4.16 & 0.77 & $0.30 *$ & -2.202 & 62 & 0.33 \\
\hline $\begin{array}{l}\text { I have already made my decision } \\
\text { about college and major. }\end{array}$ & 3.61 & 0.98 & 3.63 & 1.03 & 0.02 & -0.101 & 61 & 0.02 \\
\hline ASNR is a scientific area of study. & 3.49 & 0.81 & 3.8 & 0.89 & $0.31 * *$ & -2.746 & 60 & 0.364 \\
\hline $\begin{array}{l}\text { ASNR is a highly technical field of } \\
\text { study. }\end{array}$ & 3.19 & 0.81 & 3.61 & 0.92 & $0.42 * *$ & -3.493 & 61 & 0.485 \\
\hline $\begin{array}{l}\text { Courses in Biology, Calculus, and } \\
\text { Chemistry are not needed for most } \\
\text { careers in ASNR. }\end{array}$ & 2.56 & 0.96 & 2.61 & 1.16 & 0.05 & -0.306 & 61 & 0.047 \\
\hline
\end{tabular}




\section{Urban Youth Perceptions of Agriculture}

college and major were not different between pre- and post-questionnaires. The HSAI did not affect either student attitudes toward majoring in ANR sciences as a path to professional schools (Table 3) or their perceptions about the need for an agricultural background (Table 2). This is consistent with Swanson's (1972) theory that "knowledge and experiences are precursors to attitudinal changes and should occur before behavior can change" (p. 22).

When asked about the importance of scholarship offers when choosing colleges or majors, the students put more importance on scholarships after attending the program $(p=0.031)$ (Table 1). During the program, CASNR representatives explained that the college maintains a large pool of scholarships, with the likelihood of obtaining one being particularly high. These scholarships are offered in conjunction with, rather than instead of, other University of Tennessee scholarships. The highest means in both the pre- and post-questionnaires were in answer to the statement, "Scholarship offers are the most important factor for choosing a college or a major." These findings suggest that scholarships should be featured in recruiting materials for urban students.

\section{Knowledge of ANR careers}

The HSAI on-campus program focused on ANR careers; therefore, an increase in students' awareness of career paths within the ANR sciences was expected. More students felt that they were able to describe a career in ANR ( $p=0.037)$ after participating in the program, and more students were able to say they knew someone with a career in ANR $(p=0.041)$ (Table 3$)$ from exposure to the program. Each booth in the academic browse session highlighted a variety of career options available within each major, which explains why more students felt more confident in describing ANR careers. It is curious that after having spoken to members of the college, participating students purported to know someone personally who works in ANR. A simple explanation for the increase is that participating students were exposed to a number of faculty, staff, and students in ANR, and those were the individuals they referred to during their post-questionnaire. Another possibility is that after gaining a clearer understanding of the breadth of careers contained within ANR, students may have realized that more people in their lives are engaged in ANR careers than they originally thought. Student perceptions of ANR careers as ones involving a great deal of manual labor or the necessity of growing up on a farm did not change with programming (Table 2). 
Journal of Youth Development | http://jyd.pitt.edu/ | Vol. 12 Issue 3 DOI 10.5195/jyd.2017.497

Urban Youth Perceptions of Agriculture

Table 2. HSAI Survey Items Focused on Knowledge of ASNR Careers

\begin{tabular}{|c|c|c|c|c|c|c|c|c|}
\hline & \multicolumn{2}{|c|}{ Pre } & \multicolumn{2}{|c|}{ Post } & \multirow[t]{2}{*}{ Diff. } & \multirow[t]{2}{*}{$\mathbf{t}$} & \multirow[t]{2}{*}{ df } & \multirow{2}{*}{$\begin{array}{l}\text { Effect } \\
\text { size }\end{array}$} \\
\hline & Mean & SD & Mean & SD & & & & \\
\hline I can describe one career in ASNR. & 2.86 & 1.03 & 3.19 & 0.93 & $0.33 *$ & -2.126 & 62 & 0.336 \\
\hline $\begin{array}{l}\text { Growing up on a farm is necessary } \\
\text { for a career in ASNR. }\end{array}$ & 2.72 & 1 & 2.77 & 0.92 & 0.05 & -0.375 & 60 & 0.052 \\
\hline $\begin{array}{l}\text { Owning and operating a farm is } \\
\text { necessary for a career in ASNR. }\end{array}$ & 2.73 & 0.93 & 2.89 & 0.99 & 0.16 & -1.12 & 63 & 0.166 \\
\hline $\begin{array}{l}\text { I personally know someone who } \\
\text { has a career in ASNR. }\end{array}$ & 2.51 & 0.98 & 2.85 & 0.99 & $0.34 *$ & -2.085 & 60 & 0.345 \\
\hline $\begin{array}{l}\text { Most careers in ASNR involve a } \\
\text { great amount of manual labor. }\end{array}$ & 3.44 & 0.82 & 3.32 & 0.8 & -0.12 & 0.97 & 62 & 0.148 \\
\hline $\begin{array}{l}\text { When I hear the words ASNR, I } \\
\text { usually think of farms with crops } \\
\text { and animals. }\end{array}$ & 3.39 & 0.86 & 3.26 & 1.02 & -0.13 & 1.00 & 61 & 0.138 \\
\hline $\begin{array}{l}\text { Future salary should be the major } \\
\text { factor for choosing a career. }\end{array}$ & 3.35 & 0.99 & 3.40 & 0.98 & 0.05 & -0.293 & 61 & 0.051 \\
\hline
\end{tabular}

$* p<.05$

\section{Knowledge of Current Issues in ANR Disciplines}

The HSAI had little effect on student perception of knowledge regarding the USDA Priority Areas. Students' confidence in their abilities to discuss global food security-related issues decreased, but there was no change in perceived knowledge in the other areas (Table 3). This is consistent with other studies with short-term educational programming. Faze et al. (2011) found students participating in workshops on agricultural communications perceived that they knew less after the program than they did prior even though tests of knowledge were not different. Our programming may have challenged student views of food security and ultimately altered their perception, which caused them to rethink how well informed they were on the discussion of food security. 
Journal of Youth Development | http://jyd.pitt.edu/ | Vol. 12 Issue 3 DOI 10.5195/jyd.2017.497 Urban Youth Perceptions of Agriculture

Table 3. HSAI Survey Items Focused on Knowledge of Current Issues in ASNR Disciplines

\begin{tabular}{|c|c|c|c|c|c|c|c|c|}
\hline & \multicolumn{2}{|c|}{ Pre } & \multicolumn{2}{|c|}{ Post } & \multirow[t]{2}{*}{ Diff. } & \multirow[t]{2}{*}{$\mathbf{t}$} & \multirow[t]{2}{*}{ df } & \multirow{2}{*}{$\begin{array}{l}\text { Effect } \\
\text { size }\end{array}$} \\
\hline & Mean & SD & Mean & SD & & & & \\
\hline $\begin{array}{l}\text { Making a contribution to society } \\
\text { should be the major factor for } \\
\text { choosing a career. }\end{array}$ & 3.47 & 0.95 & 3.65 & 0.82 & 0.18 & -1.26 & 59 & 0.203 \\
\hline $\begin{array}{l}\text { Majoring in ASNR will be seen as a } \\
\text { negative when applying to } \\
\text { professional school such as } \\
\text { medical school. }\end{array}$ & 2.87 & 0.71 & 2.70 & 0.93 & -0.17 & 1.313 & 62 & 0.205 \\
\hline $\begin{array}{l}\text { I am well aware of the climate } \\
\text { change issue and can easily } \\
\text { defend my position or opinion. }\end{array}$ & 3.44 & 0.82 & 3.53 & 0.92 & 0.09 & -0.59 & 58 & 0.103 \\
\hline $\begin{array}{l}\text { My parents would be supportive if } \\
\text { I decide to pursue a career in } \\
\text { ASNR. }\end{array}$ & 3.87 & 0.92 & 3.81 & 0.88 & -0.06 & 0.429 & 62 & 0.067 \\
\hline $\begin{array}{l}\text { I can define sustainable energy } \\
\text { and provide an example. }\end{array}$ & 3.39 & 1.05 & 3.34 & 0.98 & 0.05 & 0.369 & 58 & 0.049 \\
\hline $\begin{array}{l}\text { I understand the issue of } \\
\text { childhood obesity and can make } \\
\text { at least one recommendation to } \\
\text { address this problem. }\end{array}$ & 3.87 & 0.9 & 3.69 & 0.78 & -0.18 & 1.527 & 61 & 0.214 \\
\hline $\begin{array}{l}\text { I can define global food security } \\
\text { and can discuss at least one issue } \\
\text { related to it. }\end{array}$ & 3.4 & 0.81 & 3.15 & 0.94 & $-0.25^{*}$ & 2.12 & 59 & 0.285 \\
\hline $\begin{array}{l}\text { I know about food safety and can } \\
\text { describe at least one food borne } \\
\text { illness, likely source, and } \\
\text { symptoms. }\end{array}$ & 3.62 & 1 & 3.43 & 0.97 & -0.19 & 1.286 & 60 & 0.193 \\
\hline
\end{tabular}

$* p<.05$ 


\section{Urban Youth Perceptions of Agriculture}

\section{Discussion}

Researchers have explored the factors that affect self-efficacy in predicting student achievement, course selection and potential career decision over the past 30 years (American Association of University Women, 1992; Catsambis, 1995; Dick \& Rallis, 1991; Linn \& Hyde, 1989; Oakes, 1990). This body of research consistently shows that students begin ruling out STEM careers as early as middle school. The HSAI program targeted $10^{\text {th }}$-grade students for a single intervention, however, in further reflection and based on the results of this study, we believe that establishing long-term partnerships with Title I urban high schools may be more effective at increasing the number of youth who actually apply to and enroll in ANR programs in college. Additionally, we believe these partnerships should be expanded to include the elementary and middle schools that feed these Title I urban high schools so youth are encouraged to take the STEM courses needed for ANR fields.

The urban Title I high school that participated in the HSAI currently maintains several active student organizations focusing on STEM professions (including the Environmental Science Club, Health Occupations Students of America Association and the National Technological Honor Society). These types of clubs are present in most U.S. high schools. For future HSAIs or similar events, we intend to send representatives to these particular student organizations, along with general science classes to deliver engaging and highly interactive classroom activities, mentor student projects and provide presentations and exhibits on ANR topics. Doing so will allow ANR representatives to connect with students and establish intentional partnerships that might include creating secondary university visits for urban Title I students, engaging in collaborative community service projects with ANR college students/classes, facilitating special high school science competitions on the college campus, and developing pre-college ANR summer programs for high school students. The combination of educational partnerships at the urban Title I schools and educational activities on the college campus could be utilized to potentially increase the number of urban students considering academic and professional opportunities within the ANR field.

Providing students with the opportunity to engage in tasks and activities and explore different fields in ANR was the main focus of the educational sessions. The HSAI program was successful at providing hands-on learning experiences that actively engaged participants in developing an awareness and understanding of ANR fields. Urban students with limited ANR experience were provided opportunities to touch animal pelts (i.e. gray fox, beaver, raccoons), explored a model of a cow's stomach, and answer soil science trivia questions. Bandura (1986) theorized that 
Urban Youth Perceptions of Agriculture

students develop their self-efficacy beliefs through four sources: mastery experience, vicarious experience, social persuasion, and physiological state. Specifically, the mastery experience affords students the opportunity to engage in experiential activities, decipher the results of their actions, use these results to develop beliefs to build upon future experiential activities and act in concert with beliefs created. Upon reflection, we believe that the academic browse session could be expanded so that students would have more structured time with each department to engage in meaningful, mastery-based experiences.

\section{Conclusion and Recommendations}

The main purpose of this program was to determine if short-term programming altered student perception of agricultural careers. The HSAI appears to be effective at increasing high school student knowledge of postsecondary opportunities in agriculture and natural resources. This program and study should be replicated with other populations of high school students. Through a combination of intentional activities and programing, participants were exposed to new areas of ANR studies and obtained a deeper understanding of emerging agricultural issues. As we look to the future, scholars should identify ways to increase the number of urban candidates entering the ANR workforce in the upcoming decades. To accomplish this task, educational and agricultural specialists should seek ways to provide urban and underserved student populations with consistent early exposure to the academic and professional opportunities in the ANR field.

\section{References}

American Association of University Women. (1992). How schools shortchange girls: A study of major findings of girls and education. Washington, D.C.; American Association of University Women. Anderson, J. C., \& Kim, E. (2009). Youth leadership development: Perceptions and preferences of urban students enrolled in a comprehensive agriculture program. Journal of Agricultural Education, $50(1), 8-20$.

Arrington, L. R., \& Price, W. N. (1983, December). Relationship of vocational agriculture student satisfaction to selected student, school and program variables. Paper presented at the Tenth Annual National Agricultural Education Research Meeting, Anaheim, CA.

Bandura, A. (1986). Social foundations of thought and action: A social cognitive theory. Englewood Cliffs, NJ: Prentice-Hall. 


\section{Urban Youth Perceptions of Agriculture}

Boekeloo, B. O., Jones, C., Bhagat, K., Siddiqui, J., \& Wang, M. Q. (2015). "The role of intrinsic motivation in the pursuit of health science-related careers among youth from underrepresented low socioeconomic populations." Journal of Urban Health-Bulletin of the New York Academy of Medicine, 92(5), pp. 980-994.

Bowen, B.E. (1987, December). A minority perspective on minorities in agriculture. The Agricultural Education Magazine, 60(6), 3-4.

Bowen, B.E. (1994, June). Reflections on the need for diversity: Desegregation vs. integration. The Agricultural Education Magazine, 66(12), 6-8.

Bowman, M.L. \& Shepard, C.L. (1985). Introducing minorities to natural resource career opportunities. Ohio Journal of Science, 85(I), 29-33.

Catsambis, S. (1995). Gender, race, ethnicity, and science education in the middle grades. Journal of Research in Science Teaching, 32(3), 243-257.

Cecchettini, C.L., Sommer, R., \& Leising, J.G. (1992). Australians students' perceptions of agricultural careers. Journal of Agricultural Education Spring 1992:30-37.

Dick, T P., \& Rallis, S. F. (1991). Factors and influences on high school students' career choices. Journal for Research in Mathematics Education, 22, 281-292.

Drew, J. C., Oli, M. W., Rice, K. C., Ardissone, A. N., Galindo-Gonzalez, S., Sacasa, P. R., ... Triplett, E. W. (2015). Development of a distance education program by a land-grant university augments the 2-year to 4-year STEM pipeline and increases diversity in STEM. PLOS One 10(4). Retrieved from https://doi.org/10.1371/journal.pone.0119548

Dumas, J. A. (2014). Factors that influence Black and Latino high school students to pursue careers in agriculture (Unpublished master's thesis). Pennsylvania State University, State College.

Dyer, J. E., Breja, L. M., \& Andreasen, R. J. (1999). Attitudes of college of agriculture freshmen toward agriculture. Journal of Agricultural Education 40(2):1-10.

Dyer, J. E., Lacey, R., \& Osborne, E. W. (1996). Attitudes of University of Illinois College of Agriculture freshmen. Journal of Agricultural Education 37, 33-42.

Faulkner, P.E., Baggett, C.D., Bowen, C.F., \& Bowen, B.E. (2009). Attitudes, educational, and career choices of food and agricultural sciences institute participants. Journal of Agricultural Education $50(1): 45-56$.

Faze, L. B., Wingenbach, G., Rutherford, T., \& Wolfskill, L. A. (2011). Effects of a recruitment workshop on selected urban high school students' self-efficacy and attitudes toward agriculture as a subject, college major, and career. Journal of Agricultural Education 52(4):123-135.

Flemming, M. J., \& Grace, D.M. (2015). Eyes on the future: The impact of a university campus experience day on students from financially disadvantaged backgrounds. Australian Journal of Education, 59(1), pp. 82-96. 


\section{Urban Youth Perceptions of Agriculture}

Henry, K. A., Talbert, B. A., \& Morris, P. V. (2014). Agricultural education in an urban charter school: Perspectives and challenges. Journal of Agricultural Education, 55(3), 89-102.

Hunte, C.N. (1992). The African experience in agriculture. Agriculture and Human Values, 9(I), 11-14.

Jones, K. R., \& Bowen, B. E. (1998). A qualitative assessment of teacher and school influences on African American enrollments in secondary agricultural science courses. Journal of Agricultural Education, 39(2), 19-29.

Kuijpers, M., Meijers, F., \& Gundy, C. (2011). The relationship between learning environment and career competencies of students in vocational education. Journal of Vocational Behavior, 78(1), 21-30. DOI:10. 1016/j.jvb.2010.05.005

Larke, A., Jr., \& Barr, T. P. (1987, December). Promoting minority involvement in agriculture. The Agricultural Education Magazine, 60(6), 6-7.

Lawrence, S., Rayfield, J., Moore, L. L., \& Outley, C. (2013). An analysis of FFA chapter demographics as compared to schools and communities. Journal of Agricultural Education, 54(1), 207-219.

Lent, R. W., Brown, S. D., \& Hackett, G. (1994). Toward a unifying social cognitive theory of career and academic interest, choice, and performance. Journal of Vocational Behavior, 45(1), 79-122.

Linn, M. C., \& Hyde, J. S. (1989). Gender, mathematics, and science. Educational Research, 18, 17-19.

Martin, C. K, Erete, S., \& Pinkard, N. (August, 2015). Developing focused recruitment strategies to engage youth in informal opportunities. Proceedings of the Research in Equity and Sustained Participation in Engineering Computing and Technology, Charlotte, NC,USA, 1. doi: 10.1109/RESPECT.2015.7296522

Mason, E., \& Hansen, J. (2004). Closing the color gap in teaching: A study on African American middle school students' perceptions of teaching. National Forum of Teacher Education Journal, 14(3), 111.

Newsom-Stewart, M. \& Sutphin, H. D. (1997). How tenth grade students perceive agriculture and environmental science: Comparison by gender and ethnicity. Journal of Agricultural Education 35(3): 50- 56.

Oakes, J. (1990). Opportunities, achievement, and choice; Women and minority students in science and mathematics. Review of Research in Education, 16, 153-222.

Office of Institutional Research. (2017). Official enrollment statistics: Fall 2016. Retrieved from https://oira.utk.edu/reports/fb.enrollmentstats?year=201640\&college=Agri\%20Sci\%20and\%20Natural\%20Resources\&\&\& on July 18 , 2017.

Osborne, E. W., Dyer, J. E. (2000). Attitudes of Illinois agriscience students and their parents toward agriculture and agricultural education programs. Journal of Agricultural Education 41(3), 50-59.

Outley, C. W. (2008). Perceptions of agriculture and natural resource careers among minority students in a national organization. In D. J. Chavez, P. L. Winter, \& J. D. Absher (Eds.), Recreation visitor 


\section{Urban Youth Perceptions of Agriculture}

research: Studies of diversity, (pp. 139-153). Albany, CA: U.S. Department of Agriculture, Forest Service, Pacific Southwest Research Station.

Rawls, W.J. \& Thomas, S. (1994). Analysis of student educational levels on knowledge of and interest in clusters of work-traits related to selected food and agricultural science careers. Summary of research series No. 3. Baton Rouge, LA: Southern University and A\&M College, Department of Vocational Education.

Scofield, G. G. (1995, March). College of agriculture new student profile. Paper presented at the Central Region 49th Annual Research Conference in Agricultural Education, St. Louis, MO.

Smith, B., \& Baggett, C. (2012). Perceptions of agriculture and perceived enrollment barriers to agricultural programs of select southern New Jersey high school students. NACTA Journal, 56(1), 48-56.

Swanson, J. C. (1972). Beyond thoughts on knowledge and attitude effects upon behavior. The Journal of School Health, XIII(6), 363-365.

Thompson, J. C. \& Russell, E. B. (1993). Beliefs and intentions of counselors, parents, and students regarding agriculture as a career choice. Journal of Agricultural Education, 34(4), 55-63.

Toyokawa, T., \& McLoyd, V. C. (2011). Work socialization and adolescents' work-related values in singlemother African American families. Journal of Career Development, 38(5), 1-19.

U.S. Department of Education. (n.d.). Improving basic programs operated by local educational agencies (Title I, Part A). Retrieved from https://www2.ed.gov/programs/titleiparta/index.html

U.S. Department of Education, National Center for Education Statistics. (2007). Status and trends in the education of racial and ethnic minorities. Retrieved from https://nces.ed.gov/pubs2007/minoritytrends/figures/figure_7_3.asp?referrer=report

Vincent, S. K., Henry, A. L., Anderson, J. C. (2012). College major choice for students of color: Toward a model of recruitment for the agricultural education profession. Journal of Agricultural Education, 53(4), 187-200.

Wildman, M. \& Torres, R. M. (2001). Factors identified when selecting a major in agriculture. Journal of Agricultural Education 42(2):46-56.

Wiley, Z. Z., Bowen, B. E., Bowen, C. F., \& Heinsohn, A. L. (1997). Attitude formulation of ethnic minority students toward the food and agricultural sciences. Journal of Agricultural Education 38(2):21-29. 


\section{Appendix}

\section{Survey Instrument}

\section{Agricultural Sciences and Natural Resources (ASNR) Career Attitude Survey for STUDENTS.}

Your parent has agreed for you to participate in this study, but there is no penalty if you chose not to answer any or all of the questions.

\section{Part 1. Information about you.}

Gender M F

Grew up on a farm? $\quad \mathrm{Y} \quad \mathrm{N}$
Zip Code

Participated in 4-H or FFA? $\quad \mathrm{Y} \quad \mathrm{N}$

Took at least one vocation agriculture class in high school? $\quad \mathrm{Y} N$

Took at least one environmental science class in high school? $\quad$ Y N

Part 2. Please fill in the circle $(0)$ in the box that best describes your opinion.

\begin{tabular}{|c|c|c|c|c|c|}
\hline & $\begin{array}{l}\text { Strongly } \\
\text { Agree }\end{array}$ & Agree & $\begin{array}{l}\text { No } \\
\text { Opinion }\end{array}$ & Disagree & $\begin{array}{l}\text { Strongly } \\
\text { Disagree }\end{array}$ \\
\hline $\begin{array}{l}\text { Scholarship offers are the most important } \\
\text { factor for choosing a college or a major. }\end{array}$ & 0 & 0 & 0 & 0 & 0 \\
\hline $\begin{array}{l}\text { I have already made my decision about } \\
\text { college and major. }\end{array}$ & 0 & 0 & 0 & $\mathrm{O}$ & 0 \\
\hline ASNR* is a scientific area of study. & 0 & 0 & $\mathrm{O}$ & 0 & $\mathrm{O}$ \\
\hline ASNR is a highly technical field of study. & $\mathrm{O}$ & $\mathrm{O}$ & $\mathrm{O}$ & $\mathrm{O}$ & $\mathrm{O}$ \\
\hline $\begin{array}{l}\text { Courses in Biology, Calculus, and Chemistry } \\
\text { are not needed for most careers in ASNR. }\end{array}$ & 0 & 0 & 0 & 0 & 0 \\
\hline I can describe one career in ASNR. & $\mathrm{O}$ & $\mathrm{O}$ & $\mathrm{O}$ & $\mathrm{O}$ & $\mathrm{O}$ \\
\hline $\begin{array}{l}\text { Growing up on a farm is necessary for a } \\
\text { career in ASNR. }\end{array}$ & 0 & 0 & 0 & 0 & 0 \\
\hline
\end{tabular}

* Agricultural Sciences and Natural Resources 
Journal of Youth Development | http://jyd.pitt.edu/ | Vol. 12 Issue 3 DOI 10.5195/jyd.2017.497

Urban Youth Perceptions of Agriculture

Part 2. (Continued) Please fill in the circle $(0)$ in the box that best describes your opinion.

\begin{tabular}{|c|c|c|c|c|c|}
\hline & $\begin{array}{l}\text { Strongly } \\
\text { Agree }\end{array}$ & Agree & $\begin{array}{l}\text { No } \\
\text { Opinion }\end{array}$ & Disagree & $\begin{array}{l}\text { Strongly } \\
\text { Disagree }\end{array}$ \\
\hline $\begin{array}{l}\text { Owning and operating a farm is necessary for } \\
\text { a career in ASNR. }\end{array}$ & 0 & 0 & 0 & 0 & 0 \\
\hline $\begin{array}{l}\text { I personally know someone who has a career } \\
\text { in ASNR. }\end{array}$ & 0 & 0 & 0 & 0 & 0 \\
\hline $\begin{array}{l}\text { Most careers in ASNR involve a great amount } \\
\text { of manual labor. }\end{array}$ & 0 & 0 & 0 & 0 & 0 \\
\hline $\begin{array}{l}\text { When I hear the words ANSR, I usually think } \\
\text { of farms with crops and animals. }\end{array}$ & 0 & 0 & 0 & 0 & 0 \\
\hline $\begin{array}{l}\text { Future salary should be the major factor for } \\
\text { choosing a career. }\end{array}$ & 0 & 0 & 0 & 0 & 0 \\
\hline $\begin{array}{l}\text { Making a contribution to society should be } \\
\text { the major factor for choosing a career. }\end{array}$ & 0 & 0 & 0 & 0 & 0 \\
\hline $\begin{array}{l}\text { Majoring in ASNR will be seen as a negative } \\
\text { when applying to professional school such as } \\
\text { medical school. }\end{array}$ & 0 & 0 & 0 & 0 & 0 \\
\hline $\begin{array}{l}\text { I am well aware of the climate change issue } \\
\text { and can easily defend my position or opinion. }\end{array}$ & 0 & 0 & 0 & 0 & 0 \\
\hline $\begin{array}{l}\text { My parents would be supportive if I decide to } \\
\text { pursue a career in ASNR. }\end{array}$ & 0 & 0 & 0 & 0 & 0 \\
\hline $\begin{array}{l}\text { I can define sustainable energy and provide } \\
\text { an example. }\end{array}$ & 0 & 0 & 0 & 0 & 0 \\
\hline $\begin{array}{l}\text { I understand the issue of childhood obesity } \\
\text { and can make at least one recommendation } \\
\text { to address this problem. }\end{array}$ & 0 & 0 & 0 & 0 & 0 \\
\hline $\begin{array}{l}\text { I can define global food security and can } \\
\text { discuss at least one issue related to it. }\end{array}$ & 0 & 0 & 0 & 0 & 0 \\
\hline $\begin{array}{l}\text { I know about food safety and can describe at } \\
\text { least one food borne illness, likely source, } \\
\text { and symptoms. }\end{array}$ & 0 & 0 & 0 & 0 & 0 \\
\hline
\end{tabular}

